\title{
Multiple osteochondromas
}

INSERM

\section{Source}

INSERM. (1999). Orphanet: an online rare disease and orphan drug data base. Multiple osteochondromas. ORPHA:321

Multiple osteochondromas (MO) is characterised by development of two or more cartilage capped bony outgrowths (osteochondromas) of the long bones. 